\title{
13 \\ (In)Security and Hybrid Justice Systems in Mindanao, Philippines
}

\author{
Imelda Deinla
}

\section{Introduction}

Hybridity is often conflated with the fragile state or the 'absence' of the state in a conflict environment. ${ }^{1}$ The emergence of hybrid institutions is also explained primarily in terms of the lack of capacity and legitimacy of state organs and its personnel or in the condition of a power vacuum. ${ }^{2}$ A sense of power disequilibrium or societal imbalance and disarray inheres from this presumption. Hybridity, however, serves a function that sustains conflict resilience and at the same time address immediate justice needs. Hybrids arise to provide a state of equilibrium and to provide order in an otherwise messy condition-while also contributing to the messiness. My study of the Autonomous Region of Muslim Mindanao (ARMM), Philippines, points to how hybrid justice mechanisms have developed to cope with insecurity arising from actual and perceived injustices in the community. ${ }^{3}$

\footnotetext{
1 Boege et al., 'Hybrid Political Orders, Not Fragile States'; Boege et al., On Hybrid Political Orders; Clements et al., 'State Building Reconsidered'.

2 Ibid.

3 This article is part of a broader study on plural justice, women and peacebuilding in ARMM through an Australian Development Research Award Scheme grant. Data collection was undertaken from 2014 to 2016 by conducting a justice provider survey (using qualitative methods of interviews and focus group discussions) and a justice user survey (using more quantitative, face-to-face survey
} 
In this region where almost 90 per cent of the population are Muslims with a long history of resistance to colonialism and central state authority, hybrid justice mechanisms are drawn from a panoply of customary, Islamic and state legal practices and personnel. ${ }^{4}$ Hybrid mechanisms operate through informal and formal networks to deliver 'justice' and secure the community from further escalation of violence arising from retribution. While most hybrids are local innovations and assured by the predominance of, or coalition of, local power holders, local-national innovation has also emerged in responding to local demands for speed, flexibility and adequacy of remedies and outcomes. Some form of stateled hybridity has also emerged and offers some insights on enhancing the delivery of effective and relevant justice services through professional and culturally attuned justice personnel. This may provide a counterbalance to other forms of hybrids that capitalise on power asymmetry and discriminatory practices.

\section{Statebuilding, hybrid legal order and justice}

The term 'hybrid political order' is a fairly recent conceptual tool to describe a condition where 'diverse and competing authority structures, sets of rules, logics of order, and claims of power co-exist, overlap, interact, and intertwine. ${ }^{5}$ Hybridity can be observed in many plural and multi-ethnic environments but it is in conflict and postconflict regimes that hybrid political orders are expressed more concretely. This has given academics, policymakers and development workers a better understanding of the complex and multilayered nature of rules and norms that operate in conflict-affected environments. An appreciation of hybridity has increasingly become relevant in peacebuilding and development programming by a range of actors. It has become a useful approach to describe a state of flux, nonlinear movement of change and

\footnotetext{
instruments in selected areas in Mindanao). All interviews and focus group discussions are anonymised to protect the identity of respondents. Special thanks to Professor Veronica Taylor, co-investigator in this project, and local partners: Dr Acram Latiph, Araceli Habaradas, Amanah Busran Lao, Alamira Alonto, National Commission for Muslim Filipinos, Office of the Court Administrator Supreme Court of the Philippines, Nisa ul Haq Bangsamoro, Teduray Lambiangan Women's Organization and Public Attorney's Office for support in data collection. Opinions expressed in this article are the sole responsibility of the author.

4 See Deinla and Taylor, 'Towards Peace'.

5 Boege et al., 'Hybrid Political Orders, Not Fragile States', 17.
} 
spheres of influence, the crisscrossing of actors in various domains aside from highlighting the non-exclusivity and non-privilege of state authority as a source of law, order and security. ${ }^{6}$

Hybridity has also challenged conventional views about the process of statebuilding, particularly in conflict-affected regions. The conventional perspective makes an association between hybridity and a weak or fragile state. It follows from this assumption that dispersion of authority or power structures may not be conducive to building sustainable peace and development. This view takes an opposite or less enthusiastic appreciation for the role of hybrid and other informal institutions in building sustainable peace and strengthening state institutions. ${ }^{7}$ Objections are centred on their ad hoc flexible nature, persistence of discriminatory practices and the tendency of certain arrangements to privilege, and thus exclude, a particular class of people over other groups. For instance, an 'exclusive' hybrid political order limits key political functions to a small group of elites who have control or monopoly of power. On the other hand, and showing case studies of different hybrid sites, several authors put forward an argument that makes the case for hybrid structures. They argue that being derived from or being mediated by historically and organically grown institutions such as kinship-based and traditional informal institutions, hybrids are in fact valuable owing to their strong social embeddedness and local legitimacy. ${ }^{8}$

The main enquiry for this chapter is to re-examine statebuilding processes and hybridity, and their relationship with the provision of justice in a conflict-affected area. The World Bank Development Report 2011 points to 'injustice' as one of the major causes of conflict and vulnerability of the state system.' Why has conflict, particularly what is termed 'lowintensity' conflict, endured for decades? In this condition, the state remains - though obscurely_-and state institutions continue to provide a modicum of public goods to the people. In areas where conflict and the cycle of violence have persisted, the terms 'justice' and 'injustice'

6 Boege et al., 'Hybrid Political Orders, Not Fragile States'; Boege et al., On Hybrid Political Orders; Boege et al., 'States Emerging from Hybrid Political Orders'; Kraushaar and Lambach, 'Hybrid Political Orders'; Mac Ginty, 'Hybrid Peace'.

7 See, for example, Fritz and Rocha Menocal '(Re)building Developmental States'; Ghani et al., 'An Agenda for State Building in the Twenty-First Century'.

8 See, for example, Boege et al., States Emerging from Hybrid Political Orders; Clements et al., 'State Building Reconsidered'; Höglund and Orjuela, 'Hybrid Peace Governance and Illiberal Peacebuilding in Sri Lanka'; Wiuff Moe, 'Hybrid and "Everyday" Political Ordering'.

9 World Bank, World Development Report 2011, 7, 82. 
may not be mutually exclusive, while a dichotomy between a weak and strong state may be an oversimplification. By examining the nature and operation of a hybrid justice system in Mindanao, I will show the high degree of entanglement between society and the state that has allowed for a condition of 'stability' and sustained and reinforced both traditional and modern bases of authority. This is the condition of equilibrium among different competing authorities in state and non-state sectors that is also reflected in the development of a hybrid legal order-and justice system-in Mindanao.

A corollary question in this chapter is: how viable are hybrid justice mechanisms in securing sustainable justice? Inherent in hybrids is their ability to manage or cope with instability, stress or break in social relations. ${ }^{10}$ While hybrids provide 'solutions', they also have a propensity to 'normalise' relations between opposing authorities and in the day-today interactions of communities. Using local traditions and available resources-but often underpinned by local drivers, primarily the local elites-hybrids rebalance the stresses and disequilibrium caused by disruptions, breaks, tensions and threats to 'social order'. In tackling this issue, I will show the paradox of justice in Mindanao and why the cycle of violence and injustice prevails despite an explosion of various justice mechanisms that all claim to respond effectively to the justice needs of the people. This research has identified a proliferation of avenues where people in the community run to in order to seek redress for their justice issues. In varying ways and means, different justice providers render services that seek to satisfy the justice needs of individuals and families affected by disputes. What 'justice' means in Mindanao, and other contexts, may differ from Western liberal values that are centred on a fair and public trial being presided over by an impartial and impersonal judge rendering decisions backed by the state's coercive mechanisms. In this region, the participation of the affected parties and their families in discussing the offences and remedies, provision of security, payment of blood money and reconciliation are desired justice outcomes that are highly preferable over public trial and court judgement. And yet, many forms of injustice recur as frequently as they are resolved or adjudicated in many forums.

10 Boege et al., 'Hybrid Political Orders, Not Fragile States', 18. 
A key point here is that the issue is not so much whether hybrid reality needs to be taken account of but on how much or how far existing hybrid arrangements are to be part of future institutional and legal order. How do we use our knowledge of hybrid justice orders in informing or shaping a justice architecture that responds effectively to the cycle of injustice?

\section{(In)security, conflict and hybridity}

A starting point for this chapter is to see injustice as a by-product of unresolved or recurring conflicts in society. Systemic issues in the political, economic and cultural spheres-all interlinked-shape the forms and dynamics of conflicts. As many studies in Mindanao have shown, disputes have many dimensions, new forms of conflicts are created and existing ones become even more complex. ${ }^{11}$ The recurrence of conflicts further influences structural issues and the way conflicts are addressed. The escalation of conflict-particularly the intensified use of violencedrives rapid hybridisation especially in dealing with the most destructive consequences of violent conflict and in providing security and stability. Figure 13.1 illustrates the enduring relationship of conflicts and hybrid justice mechanisms.

In this research, I see the role of a hybrid justice system in performing this rebalancing role by providing 'immediate justice needs' (primarily compensation in the form of blood money) and security (often in the form of counter/contra violence against perpetrators) to 'justice seekers'. Thus the state has much to owe hybridisation for its survival in the same (or similar) manner as traditional forms of authority. Hybridisation, however, often involves compromise and convenience in a situation of dispersed authority and conflict. The lack of a critical and more deliberative form of hybridisation results in entrenching an 'exclusivist' hybrid political order of local powerful families or clans. It fosters the emergence of alternative forms of justice mechanisms that promise 'more effective and swift' delivery of justice but run counter to fundamental human rights standards. Hybridisation has also shown disproportionate or inconsistent treatment of offences or issues involving women.

11 See, for example, Abinales, Making Mindanao; Lara and Schoofs, Out of the Shadows; Quimpo, 'Back to War in Mindanao'; Torres, Rido. 


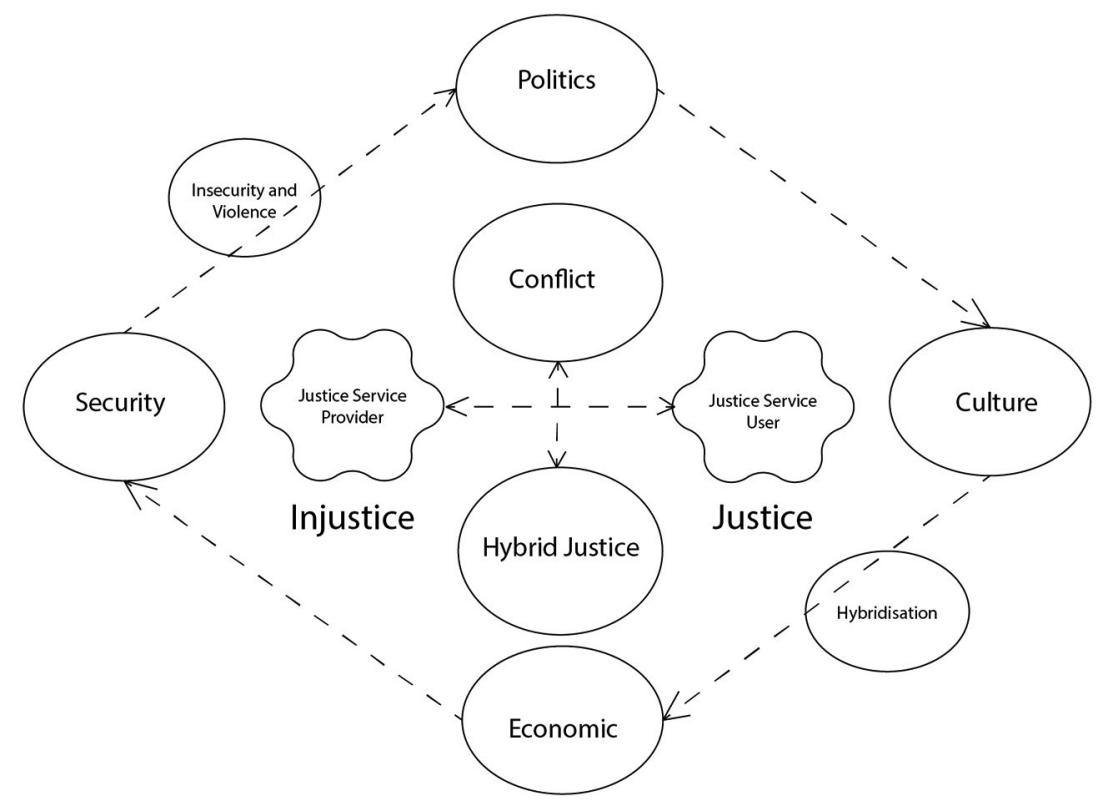

Figure 13.1: The relationship of conflict and hybrid justice mechanisms Source: Author's work.

In this chapter, I show how the interaction of conflict and local power dynamics has become the main trigger for hybridisation-on state, non-state and often the coalescing of the two sites that results in the dissolution of the binaries. Local actors perform a range of roles that do not distinguish between private, public, state and non-state functions, although these binaries or categories are often used by the actors themselves. In my research I deploy the term 'justice providers' - those who perform justice services such as by adjudication, mediation, negotiation and provision of remedies to parties, although they themselves can be both providers and users, even at the same time. In ways, these hybrid entities identify themselves as 'non-state, informal, or traditional' to differentiate themselves from entities created by the state or those that are not expressly, but in many ways, tacitly, recognised by the state. Users also recognise these binaries, and do so without realising or acknowledging that these 'informal, traditional mechanisms' are highly formalised and have appropriated elements of what they call the state formal system.

By engaging in a critical examination of how hybrids evolve, this may also allow us to determine the occurrence of 'hybrid capture'. This is a condition where particular interests dominate both process and 
outcomes for their own advantage or gain, to exclude some groups, or pursue their agenda. But even with this 'capture' we cannot also deny the agency of the users - or simply those who avail themselves of the remedies or outcomes offered by these service providers. Forum shopping has long been recognised as a feature of the existence and co-existence of different legal orders and norms, and is, if not equally, a main driving force for innovation and competition, or the process of continuous hybridisation. ${ }^{12}$

\section{Hybrid justice and security in Mindanao}

The Autonomous Region of Muslim Mindanao (ARMM) is a multiethnic region that easily lends to a highly plural and hybrid, legal order. There are at least 13 identified Muslim and non-Muslim ethnolinguistic groups. ${ }^{13}$ The largest ethnic groupings in terms of their population size are the Maguindanaoan (Maguindanao), Maranao (Lanao del Sur) and Tausug (island provinces of Basilan, Sulu and Tawi-Tawi). ${ }^{14}$ The Muslim population is estimated to be 90 per cent of the total population of 3,256,123 million people, while the rest comprise Christians and other smaller Islamised and non-Islamised ethnic groups. ${ }^{15}$ The region is composed of five provinces (Maguindanao, Lanao del Sur, Basilan, Sulu and Tawi-Tawi), formed out of a plebiscite conducted in 1989 and later in 2001 after Republic Act No. 9054 (RA 9054) was passed into law. RA 9054 incorporated the agreement in the 1996 Final Peace Agreement between the Philippine Government and the then-dominant Muslim insurgency group, the Moro National Liberation Front (MNLF), which called for the expansion of areas covered by autonomy.

Understanding the term 'justice' in Mindanao has to start from an understanding of the multilayered nature of conflict in the region and what is being demanded for the resolution of these conflicts. First, there is conflict between the state and the Moros arising from 'historical injustice' of colonisation, the formation of the Philippine state that deprived them of their claim for self-determination, and their marginalisation from

12 See Deinla and Taylor, 'Towards Peace', 27; Holbrook, 'Legal Hybridity in the Philippines', 449; Tamanaha, 'Understanding Legal Pluralism', 389.

13 Asian Development Bank, Indigenous and Ethnic Minorities and Poverty Reduction, 4.

14 See Gowing, Muslim Filipinos, 59-61; Hooker, 'Muhammadan Law and Islamic Law', 163; Jundam, Tunggal Hulah-Duwa Sarah, 10; Tan, Decolonization and Filipino Muslim Identity, 2-4.

15 Based on population census as of 1 May 2010, Philippine Statistics Authority, Philippine Standard Geographic Code, nap.psa.gov.ph/activestats/psgc/regview.asp?region=15 
central authority in terms of participation in political and economic affairs. ${ }^{16}$ Justice in this light is seen to require a recognition of the Muslim peoples' right to self-determination including their way of life and justice. Thus the first peace negotiation involving the MNLF heralded the establishment of the Shari'ah court system in Mindanao with the passage of the Code of Muslim Personal Laws of the Philippines. ${ }^{17}$

Since the formation of the Philippine state, the region has been plagued with an unabated cycle of violence that was heightened with the declaration of martial law in $1972 .{ }^{18}$ Peace negotiations have been carried out by successive governments, with the exception of the administration of Joseph Estrada that waged an 'all-out' war in Mindanao in the early 2000s. In this period, more than half a million people were displaced from their homes. Since the 1970s, it is estimated that more than 120,000 people have died resulting from or as an incidence of conflict. ${ }^{19}$ Peace agreements were signed first with the MNLF and recently with the Moro Islamic Liberation Front (MILF), a splinter group that was established in the late 1970s to fight for secessionism. The MILF negotiated with the Philippine Government for greater autonomy during Gloria MacapagalArroyo's administration but it was during the outgoing presidency of Benigno Aquino $\mathrm{Jr}$ that produced a near-culminating comprehensive peace settlement. ${ }^{20}$ In this latter peace agreement, a Comprehensive Agreement on the Bangsamoro was forged between the government and MILF that would have paved the way for the creation of the Bangsamoro entity that will exercise greater autonomy.

However, subnational conflicts are endemic in the region and are causing as much violence and crime as the insurgency war. The five provinces in ARMM have one of the highest incidences of crime in the country on a per population basis. ${ }^{21}$ The impact of this enduring conflict is seen

16 See Abinales, Making Mindanao; Bertrand, 'Peace and Conflict in the Southern Philippines'; Quimpo, 'Back to War'; Quimpo, 'Mindanao'.

17 Embodied in Presidential Decree No. 1083 (1977); see also Mastura, 'Legal Pluralism in the Philippines', 463-465.

18 Abinales, Making Mindanao; Kreuzer, Violence as a Means of Control and Domination in the Southern Philippines; Quimpo, 'Back to War'.

19 Schiavo-Campo and Judd, 'The Mindanao Conflict in the Philippines', 5.

20 The peace settlement, in particular the passage of the bill on the Bangsamoro Basic Law, was halted and derailed in the aftermath of the Mamasapano massacre on 25 January 2015 that resulted in the deaths of 44 policemen.

21 International Alert, 'Violence in the Bangsamoro and Southern Mindanao'; data for 2008-2013 gathered in this research from the Philippine National Police. 
in the deprivation and marginalisation in the social and economic life of the people in the region. All of the ARMM provinces are consistently in the bottom 10 of the poorest provinces in the Philippines. ${ }^{22}$ Insurgency and subnational conflicts also have a reciprocal relationship which fuels and sustains all types of violence and conflict. ${ }^{23}$ Inadequate state security, proliferation of firearms, the presence of different armed groups including private armies and terror and crime groups, and the weak functioning of the state justice system all contribute to a climate of violence and impunity. ${ }^{24}$

Underlying conflicts in Mindanao is the phenomenon of rido, a form of clan feuding that is rooted in the sociocultural fabric of society. ${ }^{25}$ Honour or maratabat - and its reverse, shame-is a paramount value in traditional societies in Mindanao; putting a clan's honour on the line has dire consequences for those who tarnish or undermine it. ${ }^{26}$ Individual honour, or shame, is a collective trait and responsibility such that an infraction against a person is treated as one against their family and clan. Rido can be triggered by major disputes such as political and economic competition, land disputes and violence committed to a person. ${ }^{27}$ It can also be precipitated by minor or petty issues. Interviews conducted reveal that all forms of issues are susceptible to rido. Some of the stories narrated were over disagreements on dowry and guardianship, offending family members by showing affection to a woman, and non-payment of debts. Rido is a form of dispute settlement where disputes are settled by exacting a 'score' against the opposing family or clan. Until the number of hits or fatalities are almost parity, the dispute is not considered ripe for settlement. While rido is generally seen as negative and destructive, it is widely exercised across Muslim, indigenous and Christian populations in Mindanao. My research also reveals that many favour rido as essential in order to settle disputes despite its destructive impact on the family and the community. ${ }^{28}$ As the following discussion demonstrates, rido is the force behind the dynamic hybridisation of the justice architecture in Mindanao.

22 UNDP, 'Human Development Index Highlights Inequality'.

23 On conflict morphing see International Alert, Rebellion, Political Violence and Shadow Crimes in the Bangsamoro, 28.

24 See Lara and Schoofs, Out of the Shadows.

25 Torres, Rido: Clan Feuding, 11-13.

26 Durante et al., 'Management of Clan Conflict and Rido amoung the Tausug, Magindanao, Maranao, Sama, and Yakan Tribes', 105; Torres, Rido, 20-22.

27 Torres, Rido, 16-17; also interviews conducted among justice providers; there is increasing competition over illegal economic activities such as drugs trade.

28 Justice user survey, Marawi City, Lanao del Sur province, September 2015. 


\section{Hybrid justice and security in ARMM}

The plural and hybrid justice architecture in ARMM is a by-product of its own historical development, the process of state-society formation and interaction, and of the persistence of conflicts. These three forces developed and continue to shape laws, norms and mechanisms that respond to problems or issues that community members face in their dayto-day lives. The 'everyday life' of residents in a conflict or postconflict area differs, however, from those living away from a condition of daily threats of violence and armed conflict. Often, broader social justice issues such as political exclusion and competition, economic inequality, poverty, access to education and health services, and land conflicts underlie many crimes or socially unacceptable behaviour that disrupt peace and drive further conflict in the community. For example, small crimes handled in secular courts in conflict-ridden areas involve thefts in shopping centres, money scams and non-payment of debts or loans that reflect on the dire economic condition of many people. In the aftermath of the siege of Zamboanga City by a faction of MNLF combatants, civil court judges reported high incidences of shoplifting of infant formula milk. ${ }^{29}$ These types of cases impose a heavy burden on women, who not only face the challenge of providing for the basic needs of their families but are also subject to various suits in civil courts. ${ }^{30}$

The continuation of traditional authority and norms that survived waves of Western colonisation has ensured that state formation in this region is uneven, complex and fraught with difficulties. While the process of statebuilding disrupted the further evolution of nascent state-like authority which had been based on the authority of the sultan and datu (village chief), traditional authority, through cooperation, negotiation or co-optation, ensured that the Philippine state is a constant presence in the region. The state, and its structures, has created winners and losers in the process, including by introducing a new arena for competition among families or clans. The state as a source of formal-legal power, patronage and of economic and resource opportunities provides incentives for fierce and often coercive contestation among contending elites and other authorities vying for power. ${ }^{31}$ In return, local state officials ensure the omnipresence of the

29 Interview with civil court judges, April 2014.

30 Interview with civil court judges, April 2014. According to interviews, breaches of contracts and non-payment of loans are usually the responsibility of women in the household.

31 Abinales, Making Mindanao, 188; Caballero-Anthony, 'The Philippines in Southeast Asia', 7-13; McCoy, An Anarchy of Families. 
state and provide local 'stability'. Results of the justice user survey reveal that 73 per cent of respondents feel 'secure' in their community. ${ }^{32}$ Local state elites in Mindanao, as elsewhere in the Philippines, have enjoyed autonomy from the state and even from the insurgency groups given their possession of state authority, resources and means of coercion. ${ }^{33}$

The most violent and destructive forms of rido-and the most difficult to resolve-have been fought over electoral contests and economic competition or rivalry. ${ }^{34}$ Rido, which usually happens between ethnic groups, has also become more vicious with this new layer of contestation. While women and children are generally spared from reprisals, spates of rido involving electoral competition in recent years have seen several children, elderly and women killed or brutalised. ${ }^{35}$ For these types of rido, the cycle of violence continues for years or decades even if there is cessation of hostilities and settlement of the dispute. ${ }^{36}$ It needs to be stressed that violence involving women-whether Muslim, indigenous or Christian-is borne out of this complex relationship of tradition, politics, economics and conflict that make women more vulnerable to physical, sexual, economic and emotional violence. For example, women public schoolteachers, regardless of their ethnicity, have become targets of panggoyod (forcible abduction for marriage) in the island province of Sulu due to the income they can bring to the family, or targets of physical violence for fulfilling their duties as election officials. ${ }^{37}$

The interlocking nature of conflicts in Mindanao therefore lends itself to multiple and complex processes of dispute resolution and justice outcomes. A hybrid justice system is a necessary consequence of the complex dynamics of history, politics and conflict that serves to provide

32 The justice user survey, conducted in July 2016 in ARMM, had 544 respondents: 39.5 per cent male, 57 per cent female and 3.5 per cent 'no response'. The survey was conducted in collaboration with the National Commission of Muslim Filipinos.

33 Abinales, Making Mindanao, 18; Caballero-Anthony, 'The Philippines in Southeast Asia', 11; Kreuzer, Philippine Governance'; Lara and Champain, Inclusive Peace in Muslim Mindanao, 22.

34 Durante et al., 'Management of Clan Conflict', 106-109; Lara and Champain, Inclusive Peace, 15; Lara and Schoofs, Out of the Shadows, 29-30; Torres, Rido, 16-17; qualitative interviews with justice providers. Economic competition happens in either legitimate or illicit businesses such as drugs, trafficking and gun smuggling.

35 The Ampatuan massacre in 2010 had women raped before being killed and mutilated while the rido ambush on 28 July 2014 in Sulu happened on the occasion of Eid-al-Fitr.

36 Based on interviews, some descendants would re-open rido to exact revenge. One story involved the son of a murdered man who killed his father's killer years later after settlement of rido.

37 Based on interview from respondents from Sulu; see also Alipala, 'Abducted Teacher Rescued by Soldiers in Sulu'; Fernandez, '2 Teachers Killed, 2 Hurt in Cotabato City'. 
a stabilising platform for contending authorities in the region. There are at least three layers of authority in ARMM: the state, the local or village authority, and the family or clan. ${ }^{38}$ All three have their own laws, rules and norms; each claiming their boundaries, competing to expand their power and authority, but also in the process of cooperating and deploying resources from each other. This is the state of equilibrium in the region that maintains order but also sustains the cycle of violence. This hybridity is fluid, ad hoc and composed of multiple actors who crisscross and penetrate various domains of justice provision.

My research has identified at least 16 mechanisms where people can bring their problems or issues for resolution and seek redress for the wrongsactual or perceived-they suffer from (Table 13.1). For the purpose of ease in categorisation, although this is by no means a strict classification, I outline four categories of justice provider in the region. It needs to be clarified that justice services or justice needs are the preferred terms to how people understand and describe 'justice' rather than the normative ideas of fairness and due process that are usually associated with formallegal justice. Hence, the term 'justice provider' is used to denote a more expansive list of actors and mechanisms that deliver justice services to those who need them.

Table 13.1 shows the existence of a hybrid justice system, the creation of new hybrid mechanisms and the hybridisation of existing mechanisms of justice. The four categories listed are a combination of actor-based classification and where the service provision is taking place. The state court system covers state-provided civil courts, Shari'ah courts, public prosecutors and public defenders. Its proceedings are mostly done within court or official premises and follow prescribed procedures and formalities. Non-state based courts are organised by non-state groups, in particular the insurgent groups within their areas of control or influence (that is, the MILF, MNLF and People's Court); the proceedings in these courts are also conducted in a formalised manner and in accordance with some rules to ensure due process for the parties and to gather evidence. ${ }^{39}$

38 Kreuzer, Political Clans and Violence; Adam et al., 'Hybrid Systems of Conflict Management and Community-Level Efforts to Improve Local Security in Mindanao'.

39 See Stephens, 'Islamic Law in the Philippines', 22-23; author's interviews with MILF Shari'ah court judges and People's Court cadres. 
13. (IN)SECURITY AND HYBRID JUSTICE SYSTEMS IN MINDANAO, PHILIPPINES

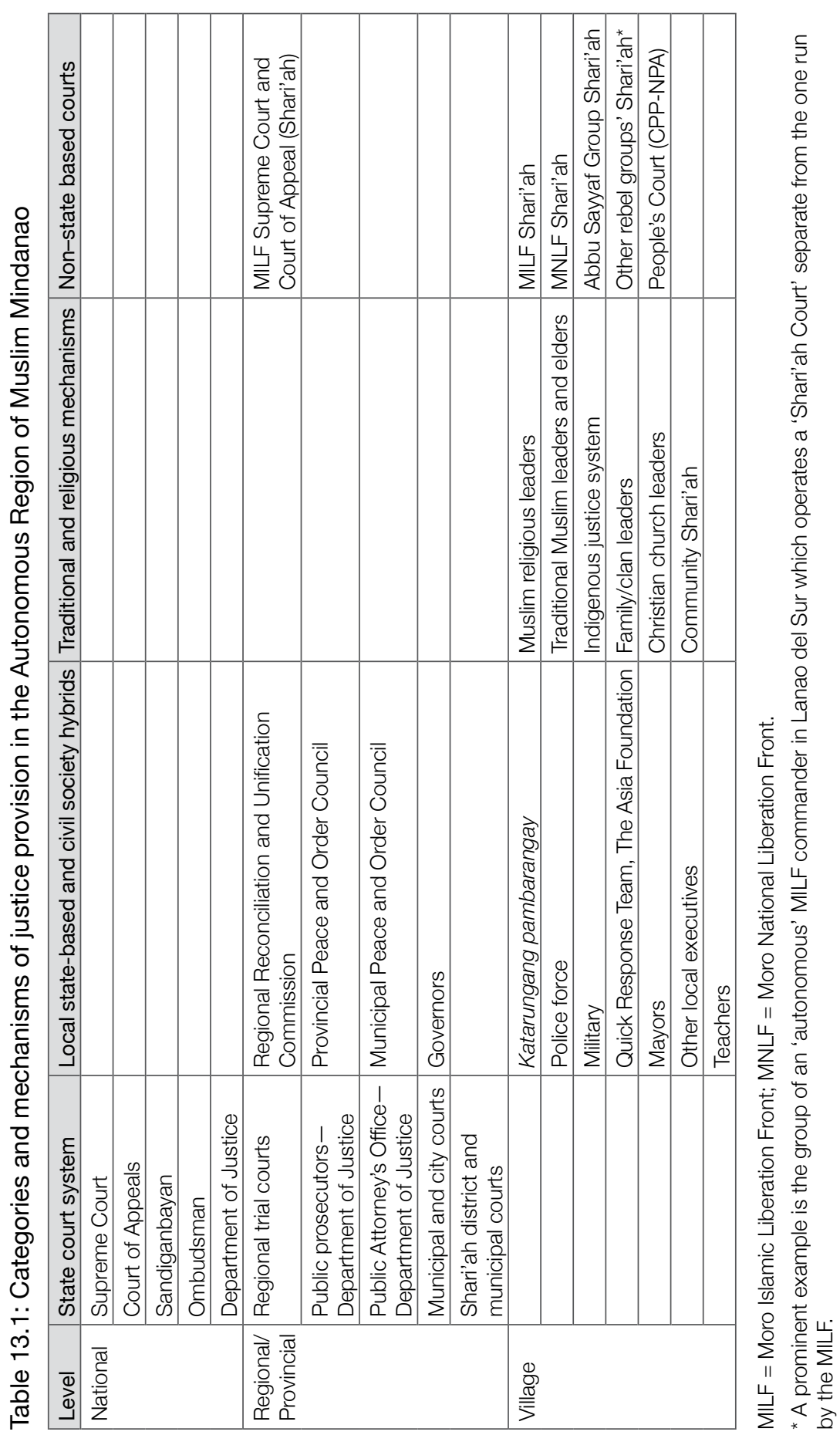


Local state-based and civil society hybrids are those established by local executives and operated mainly through local state structures as well as those developed by local non-government organisations with the support of international development organisations..$^{40}$ Similar to non-state courts, this type of justice mechanism, with the exception of the katarungang pambarangay, is a recent phenomenon that developed from local initiatives to cope with difficulties in dispensing justice in a multi-ethnic community mired in conflict. ${ }^{41}$ The formation of the Provincial Peace and Order Council and the Municipal Peace and Order Council in various places in ARMM has coincided with the increasing power of local executives as they started to receive automatic revenue appropriations from the central government in the late 1990s when the Local Government Code was passed to provide fiscal autonomy to local government units. Known as internal revenue allocation or 'IRA', this fund is intended for the delivery of basic government services but has been a source of corruption, patronage and dependence of local government units on central government authority. ${ }^{42}$ This fund has also been used by local executives in the region in dispensing their roles as justice providers, whether in the katarungang pambarangay, Municipal Peace and Order Council or Provincial Peace and Order Council, in raising funds for blood money and in defraying costs and remuneration for some personnel involved in settling disputes. ${ }^{43}$ Local executives have given 'allowances' to state civil court judges assigned in their areas. ${ }^{44}$ As local executives also gain more control over police in their areas of authority, they are able to deploy 'coercive power' of arrest and enforcement of decisions or settlement. The combination of state authority and resources, traditional authority or indigenous means of settling disputes, and flexibility in the process of dispute settlement has made this 'hybrid group' increasingly popular among the population.

The need for security, as an immediate justice outcome, shows the power dimension in the delivery of what constitutes an 'effective' justice service in a conflict environment. Almost all providers of justice interviewed were unanimous in pointing to the provision of security-for themselves, for

40 Such as the Asia Foundation's support for the Quick Response Teams.

41 Interviews with local community-based justice providers, November 2015.

42 See Santos, 'Not a Lot to Allot'.

43 Interviews with community-based justice providers.

44 Interviews with civil court judges and state Shari'ah court judges. It appears that civil court judges receive more support from local executives than their Shari'ah counterparts and that Shari'ah judges assigned in Christian-dominated local councils receive more support than those in Muslimdominated local councils. 
the parties and their families - during the process of conflict settlement as indispensable in settling disputes. ${ }^{45}$ As practically all issues, rivalry and misunderstanding can precipitate a rido, the first task for the justice provider is to ensure that no violence ensues or if it did occur that a 'ceasefire' is worked out among the clans. ${ }^{46}$ Speed in resolving the conflict is thus a necessary complement to security provision. Bringing the parties to agree to settle the dispute is a complex process that requires the justice provider to trace common lineages or relationship between the disputing clans. ${ }^{47}$ Security, speed, flexibility and participation of the parties are identified as essential in the process of justice delivery in ARMM and are synonymous with justice itself. The payment of blood money is the culmination of the process of mediation and negotiation that takes place among the justice provider, the disputing parties and their families or clans. In most cases, the justice provider is also asked to help in raising blood money and oftentimes ends up contributing their own resources for this purpose. ${ }^{48} \mathrm{~A}$ feast, called kanduli in some areas, is often held to celebrate the reconciliation of clans involved in the dispute.

Hybridisation takes place in all four categories and levels of justice services, driven by the necessity for the 'justice essentials' described above. Even in the state court system, hybridisation is taking place, albeit informally and sometimes with or without official sanction. For instance, state Shari'ah court judges have resorted to the 'traditional method' of settling disputes or run the risk of becoming 'irrelevant'. ${ }^{49}$ This mediation effort, which takes place outside the court, is not recognised as 'judicial duties' by the Supreme Court. In fact it is prohibited. Out-of-court settlement is the preferred option among justice users and this is shown in the declining number of cases being adjudicated in both civil and state Shariah court systems. ${ }^{50}$ On the other hand, the public defender's office, the Public Attorney's Office (PAO), has formally instituted a 'pre-litigation conference' process to allow PAO lawyers to mediate or settle disputes among the parties. The PAO in ARMM, which has many young Muslim

45 Various interviews with justice providers in ARMM, conducted from 2013 to 2015.

46 Various interviews with justice providers involved with settling rido, conducted from 2014 to 2015 .

47 See, for example, Menkhaus, 'Traditional Conflict Management in Contemporary Somalia', $186-187$.

48 Many of those interviewed who have had experience in resolving a rido revealed this has become a huge responsibility for them to ensure that adequate blood money is raised and often contribute their own money, animals and property for the settlement and kanduli.

49 Interview with state Shari'ah judges.

50 Court data obtained from the Supreme Court for 2008-2013. 
women lawyers as personnel, is also conducting information and outreach programs to communities. During interviews, some lawyers revealed that they combine traditional knowledge and secular rules in arriving at solutions to problems. ${ }^{51}$ Surveys conducted in this research found that, among users in ARMM, PAO lawyers are trusted and well respected by the community and the courts. ${ }^{52}$

Hybridity also reflects the rise of non-traditional actors involved and the methods by which disputes are resolved. Trust is a vital attribute that the justice user looks for in a justice provider. ${ }^{53}$ This means trust that the justice provider can provide security and deliver the best outcomes for the party and their family in the most expeditious manner. A high degree of enforcement is also correlated with trust of the person delivering the service. It is not surprising therefore that users of the hybrid justice system overwhelmingly chose 'family/clans' as the most sought after provider of justice and also with the highest trust preference. ${ }^{54}$ Elders or leaders of the clan are constituted, individually or as a group, to approach the disputing parties and their families and conduct informal mediation. A high degree of enforcement is also an attribute of rebel Shari'ah courts, which possess the ability to dispatch armed personnel for enforcement. For instance, in Lanao del Sur, a commander's court boasts of an effective justice service through its uncompromising approach in seeking out the perpetrators and rehabilitation approach combined with physical punishment and learning Qur'anic teachings and virtues. It claims that families have even voluntarily entrusted their children for drug rehabilitation. ${ }^{55}$

An increasing trend towards dispute resolution by local state executives such as elected village head chiefs and municipal, provincial and regional state officials shows how power is harnessed in delivering justice to the community. Next to clan-based justice, the second-most preferred groups of justice providers are the katarungang pambarangay, or village council mediation, composed of elected local village chiefs and the mayors. Katarungang pambarangay is a creation by law that is based on

51 Interview with PAO lawyers, Community Legal Aid providers survey.

52 Justice user survey conducted in selected areas in the five provinces of ARMM in October 2015 and June 2016.

53 Results of qualitative interviews and of the user survey.

54 Result of survey in Marawi City, Lanao del Sur and interviews with government employees in ARMM.

55 Interview with rebel Shari' ah court personnel, February 2015. This group operates a prison dug out from the ground where 'offenders' and drug users are held for some time until rehabilitation is completed. 
traditional methods of mediation and dispenses the need for lawyers. ${ }^{56}$ It is mandated to conduct mediation and to provide the avenue for an 'amicable settlement' between the parties to the conflict; its jurisdiction is limited to small criminal or civil matters. In ARMM, katarungang pambarangays have evolved into solving serious crimes or issues in the community such as murder, rido and rape. Village officials have become involved in providing security for the parties and in raising blood money. Some of them use state court methods such as issuing a 'warrant of arrest' or 'subpoena'. One account also mentions that it provides a facility for temporary detention of the parties involved in the dispute in order to prevent the escalation of further violence or to keep the person safe from retribution from the other party or clan. ${ }^{57}$

\section{Conclusion: Towards a sustainable justice?}

The existence of a hybrid justice system operating within and outside the state system reflects the complexity of conflict and power dynamics in Muslim Mindanao. It shows how the development of hybrid political order-and that of hybrid justice mechanisms-parallels the process of statebuilding in the region. This is characterised by a state highly dependent on local power structures and dispersion of power among local power holders. The state-and corresponding legal hybridity-has ensured a fluid co-existence of traditional and state authorities. This means that the state has not disappeared but functions through clan-based authority. This is demonstrated in how justice provision works through clans and the development of new hybrids that harness the resources and power of both state and traditional authorities.

The delivery of holistic or comprehensive justice services has become an important attribute of newly developed hybrid mechanisms in Mindanao. The segmentation of different pillars of justice, each working separately and with their own set of personnel, works to disadvantage state formal mechanisms of justice which need to observe pre-agreed rules and separation of justice functions from apprehension of wrongdoers, to prosecution, judicial determination and enforcement. Hybrid justice providers fill a crucial role in delivering prompt and effective justice to an

56 Provided under Presidential Decree No. 1508 and later amended by Republic Act No. 7160

(Local Government Code of 1991).

57 Interview with justice provider, Community Legal Aid. 
environment where conflict dynamics are complex. The delivery of justice and security provision are intertwined functions that require flexibility of rules, coordination of multiple actors and authoritative capacity of the justice provider. As shown in this chapter, an effective justice provider is one who possesses multiple authorities and can deploy adequate resources to meet the justice demands of parties. While justice provision is a demonstration and source of power by local elites, and susceptible to hybrid capture, it needs to be recognised that the delivery of justice is an essential public service to which hybrid and non-state justice mechanisms provide a significant contribution.

Do hybrid justice mechanisms better serve the justice interests of people in multi-ethnic and conflicted areas? We have seen in Mindanao that hybrid justice mechanisms are providing security and a more holistic approach to justice which the state court system is unable to provide. The case in ARMM shows that these mechanisms are, however, power dependent and their legitimacy is based primarily on the resources and coercive power that can be deployed to be effective. Their seats of authority are also highly contested and a source of violent conflict among competing clans, and the rules may not be applied to all, especially when the conflict involves more powerful parties. We have also seen that the state court system is undergoing hybridisation in the way it responds to demands for flexibility and speed in resolving issues by undertaking mediation and settlement functions.

Except for the Public Attorney's Office, there is reticence on the part of state authorities to officially sanction a more flexible approach to dispute settlement. As non-court state hybrids and non-state adjudication become more popular, there is a danger that state court processes may be rendered irrelevant, as they are now underutilised. The uncoordinated process of hybridisation and lack of deliberation may also serve to foster competition among various justice providers and deliver disparate and competing outcomes. This engenders heightened forum shopping and for parties to dictate the terms and process of proceedings, as is already happening. ${ }^{58}$ A hybrid justice system that is ruled by the dynamics of conflict, rather than normative ideas of justice, can deliver only palliative outcomes and does not work to deter crimes and conflicts. The complex dynamics of conflict in ARMM also show the need for sustainable hybrid justice mechanisms to connect to the realisation of social justice.

58 Interviews with various justice providers and justice users in ARMM. 
This text is taken from Hybridity on the Ground in Peacebuilding and Development: Critical Conversations, edited by Joanne Wallis, Lia Kent, Miranda Forsyth, Sinclair Dinnen and Srinjoy Bose, published 2018 by ANU Press, The Australian National University, Canberra, Australia.

doi.org/10.22459/HGPD.03.2018.13 